\title{
Conservation plans and soil and water conservation practice use: Evidence from lowa
}

\author{
C. Morris and J.G. Arbuckle
}

\begin{abstract}
Conservation planning is the primary tool the USDA Natural Resources Conservation Service (NRCS) uses to help farmers manage and protect the nation's soil, water, air, plant, animal, energy, and human natural resources on privately owned lands. While research studies have investigated a multitude of factors that could possibly influence farmer adoption of conservation practices, no recent research exists examining the relationship between having an NRCS conservation plan and the likelihood of applying conservation practices on the ground. This is surprising given that conservation planning is considered to be the foundation for USDA's technical and financial assistance to agricultural landowners, and recently both the updated NRCS Strategic Plan and the National Conservation Planning Partnership emphasized the need to enhance and expand conservation planning. In this study we analyzed data from 792 respondents of the 2015 and 2016 collection periods of a panel survey of Iowa farmers to examine the relationship between having an NRCS conservation plan and farmers' implementation of 10 soil and water conservation practices in four categories: (1) soil health, (2) nitrogen (N) management, (3) structural practices, and (4) cropland converted to perennial crops. The results indicate that farmers who reported having an NRCS conservation plan are significantly more likely to have implemented two conservation practices: no-till and terraces. In addition, there was a significant relationship between the number of times a farmer visited a USDA Service Center for conservation and the likelihood they implemented 5 of the 10 selected practices, particularly in the soil health and structural practice categories. These results suggest that it is not the plan itself, but rather the sustained interaction with natural resource professionals, that makes a difference in the use of conservation practices. Implications of the study results for NRCS conservation planning moving forward in the future are discussed.
\end{abstract}

Key words: conservation plans - conservation practice adoption-Iowa-Natural Resources Conservation Service

\begin{abstract}
Conservation planning is the primary tool the USDA Natural Resources Conservation Service (NRCS) uses to help farmers manage and protect the nation's soil, water, air, plant, animal, energy, and human natural resources on privately owned lands. Seventy percent of the land in the United States is privately owned, which makes private land stewardship critical to the nation's overall environmental health (USDA NRCS 2020a). In the Midwest in general, $93 \%$ of the land area is privately owned (Moritz 2020). In Iowa, private ownership accounts for 97\% of the land (Rasker 2019), and 93\% is rural
\end{abstract}

farmland (ISU Extension and Outreach 2020). Not only does private land encompass a large percentage of the overall landscape, but many ecologically important sites for endangered species (Scott et al. 2006) and areas that contribute disproportionally negative effects on water quality through runoff, leaching, and soil erosion (Nowak et al. 2006; Armstrong et al. 2012) are often managed by private landowners.

According to the NRCS, conservation planning is a voluntary "natural resource problem solving and management process" that "integrates economic, social, cultural,

Received October 4, 2020; Revised January 8, 2021; Accepted January 23, 2021; Published online July 26, 2021. and ecological considerations to meet private and public needs" (USDA NRCS 2006a). This approach emphasizes desired outcomes and "helps improve natural resource management, minimize conflict, and address problems and opportunities" (USDA NRCS 2006a). NRCS assists land managers with the conservation planning process ranging from site-specific plans for individuals to community, watershed, or area-wide plans for groups of land managers. NRCS duties are carried out locally through county-level conservation districts. Locally based, professional NRCS conservationists from district offices work one-on-one with individuals and groups in the field to evaluate natural resource concerns and provide technical assistance to address these concerns. This technical assistance is provided through formal agreements in cooperation with conservation district boards made up of elected local landowners who are responsible for approving conservation plans as well as identifying general natural resource concerns in the areas they represent (USDA NRCS 2006a). NRCS conservation planning and technical assistance is taxpayer-funded and is therefore offered free of charge to landowners and/or managers (USDA NRCS 2010). This approach to conservation is voluntary, meaning that it is initiated by the land manager, who contacts their local Service Center to request assistance (USDA NRCS 2020h).

The official NRCS definition of a conservation plan is "a record of decisions and supporting information for treatment of a unit of land meeting planning criteria for one or more identified natural resource concerns as a result of the planning process. The plan describes the schedule of implementation for practices and activities needed to solve identified natural resource concerns" (USDA NRCS 2020b). The conservation plan itself typically includes an aerial photo map showing property and field boundaries, a topography map, a soil map with soil descriptions, a record of the location and schedule of agreed-upon conservation practices, information sheets and engineering designs with specific information on how

Chris Morris is a PhD graduate student in the Department of Sociology at lowa State University, Ames, lowa, and J. Gordon Arbuckle is a professor in the Department of Sociology at lowa State University, Ames, lowa. 
to implement conservation practices, and operation and maintenance plans for selected practices (USDA NRCS 2013b).

Common resource concerns that can be addressed through conservation planning on farmland include soil erosion, soil quality degradation, impaired water quality, excess or insufficient water quantity, degraded plant condition, livestock production limitation, inadequate fish and wildlife habitat, inefficient energy use, and air quality impacts (USDA NRCS 2013a). NRCS conservationists work with farmers to choose from a myriad of conservation practices, also referred to as best management practices (BMPs), to address these resource concerns. Typical practices in Iowa include no-till, strip-till, cover crops, contour buffer strips, water retention structures, hay and pasture planting, farmstead feeding operations, farmstead windbreaks, nutrient management, terraces, waterways, filter strips, prairie establishment, wetland restoration, timber stand improvement, grade stabilization, feedlot runoff control, tree plantings, prescribed grazing, and bioreactors (Kuhn 2018). Because resource concerns are often caused by several converging factors, systems-based approaches with a combination of practices are favored in conservation plans over implementing individual practices. For instance, rather than just installing a waterway, a combination of terraces, waterways, and contour farming may be needed to substantially reduce erosion in a cropland field (Kuhn 2018).

NRCS utilizes a nine-step conservation planning process with the following steps: (1) identify problems and opportunities, (2) determine objectives, (3) inventory resources, (4) analyze resource data, (5) formulate alternatives, (6) evaluate alternatives, (7) make decisions, (8) implement the plan, and (9) evaluate the plan (USDA NRCS 2006a). After alternatives have been evaluated and practices have been agreed upon, the plan must be approved and signed by a certified NRCS conservation planner. The participant also signs the plan, and in most cases, the plan is approved and signed by an associate of the local Soil and Water Conservation District. If a conservation plan is required for specific USDA program requirements—such as highly erodible land compliance-the plan must also be approved by the appropriate NRCS official. A copy is given to the participant, and the original plan is kept on file in the local USDA Service Center (USDA
NRCS 2016a). NRCS considers conservation plans to be progressive and adaptive, meaning they can be updated as time goes by to address new resource concerns or reflect new management goals of the producer. One of the ideal goals of conservation planning is to work with a producer to develop a Resource Management System (USDA NRCS 2020b), which is a conservation plan that meets or exceeds the documented quality criteria required to address all resource concerns on a given land use area (USDA NRCS 2007).

Historical Perspective. The NRCS's recently updated mission statement is "We deliver conservation solutions so agricultural producers can protect natural resources and feed a growing world" (USDA NRCS 2020c), and the agency has been carrying out this mission since its inception in 1935 (USDA NRCS 2020d). Originally named the Soil Conservation Service (SCS), the agency was established during the midst of one of the nation's most environmentally and economically devastating natural disasters, the Dust Bowl (USDA NRCS 2020d.). Hugh Hammond Bennett, the soil scientist who advocated for the establishment of the SCS and who eventually became its first chief, realized the eminent importance of preserving the nation's natural resources. In 1939 he wrote, "Unless the United States goes ahead vigorously, persistently, and speedily to defend and conserve the soil and to make far-reaching adjustments in its complex land economy, national decadence lies ahead" (Bennett 1939). Known as the "father of soil conservation," Bennett emphasized the importance of locally led conservation efforts, and he structured the federal agency with field offices established in local conservation districts at the county level across the entire nation (USDA NRCS 2020d). He also emphasized the role of local conservation planners to help deliver scientifically based conservation knowledge, technology, and planning that is tailored to individual farmers' needs. In 1943 he wrote, "Many farmers - most farmers, and that means millions-need some technical help in making the change to this more efficient, easier, and more productive type of farming, and they need also moral support and encouragement" (Bennett 1943).

Over the next few decades following its establishment, the SCS continued to provide technical assistance to farmers, and the num- ber of conservation districts grew. During the 1950s, the SCS began providing technical assistance for federally legislated programs like the Soil Bank Program, which focused on financially incentivizing long-term retirement of highly erodible and environmentally sensitive lands from production, and the Great Plains Conservation Program, which provided financial assistance for conservation practices (USDA NRCS 2020d).

Growing public concern about the health of the environment during the 1960s and 1970s resulted in federal agencies being tasked with greater oversight of environmental concerns (USDA NRCS 2020d). With the passage of the 1985 Food Security Act (also known as the 1985 "Farm Bill”), certain conservation plans became mandatory for participation in USDA financial farm commodity and conservation programs for producers who were farming officially designated highly erodible land (HEL; "sodbuster provisions") or land with wetlands ("swampbuster provisions"). These conservation compliance plans were developed specifically to reduce soil erosion or to protect wetlands and were therefore fairly basic, consisting of a small number of required practices. Additionally, these plans were created only for fields officially designated as being either highly erodible or containing wetlands and were not total farm plans (Claassen 2004). The 1985 Farm Bill also introduced the Conservation Reserve Program (CRP), an update of the 1956 Soil Bank Program (Coppess 2017).

In the mid-1990s, to better reflect the broad scope of the agency's mission, the agency was renamed the Natural Resources Conservation Service through the Department of Agriculture Reorganization Act of 1994 (USDA NRCS 2020d). Because conservation practices can be expensive to implement, the NRCS began to place greater emphasis on working lands conservation financial assistance programs, such as the Environmental Quality Incentives Program (EQIP), in an effort to increase conservation practice adoption (USDA NRCS 2020e). Research on additionality, defined as "a measure of the effectiveness of voluntary payment programs at inducing the adoption of conservation practices that would not have been adopted in absence of the payments from the program" (Claassen and Duquette 2012), has shown that the majority of farmers who implement conservation 
practices with funding assistance through NRCS financial programs would not have implemented those practices without that financial assistance (Claassen and Duquette 2012). While conservation plans are separate from financial program contracts, the NRCS recommends that farmers develop a conservation plan with an NRCS planner prior to making an application for a financial program contract (USDA NRCS 2016b). Since the 1990s, there has been a shift toward more NRCS employee time spent working on the administrative aspects of financial assistance programs, but none of these programs would be possible without conservation planning as an integral part of the process (Helms 2005).

NRCS conservation planning is administered through the Conservation Technical Assistance program (CTA). The CTA program is the largest NRCS program, and it is funded through the agency's Conservation Operations (CO) discretionary funds (USDA OBPA 2020). The CTA program enables other NRCS programs by facilitating conservation planning and assisting in preparing landowners and decision-makers for participation in USDA conservation financial assistance and easement programs (USDA NRCS 2006b). These include popular programs funded through subsequent versions of the farm bill, like the CRP, EQIP, the Conservation Stewardship Program (CSP), the Agriculture Management Assistance program (AMA), and the Agriculture Conservation Easement Program (ACEP) (USDA NRCS 2020e). Additionally, NRCS State Conservationists may use conservation plans as part of the qualification criteria for participating in these financial assistance and easement conservation programs (USDA NRCS 2006b). Conservation planning is also provided to assist agricultural producers in complying with the HEL and Wetland Conservation Compliance provisions of the 1985 Food Security Act, which, as mentioned earlier, is also a requirement for participating in USDA conservation programs (USDA NRCS 2020f).

In addition to providing conservation planning technical assistance for financial programs, there has been an agency-wide push in recent years to improve and expand conservation planning in and of itself (USDA NRCS 2020g). The National Conservation Planning Partnership (NCPP) is a national initiative that was developed in 2015 between the NRCS, the National Association of Conservation Districts (NACD), the National Association of State Conservation Agencies (NASCA), the National Association of Resource Conservation and Development Councils (NARC\&DC), and the National Conservation Districts Employees Association (NCDEA). This initiative has the goals of (1) reinvigorating conservation planning, (2) improving the capacity to deliver one-on-one conservation planning assistance, (3) ensuring the delivery of voluntary, science-based assistance, and (4) building and sustaining a workforce of strong conservation planners (NACD 2017). Additionally, the newest version of the NRCS Strategic Plan calls for a strategic goal of strengthening, enhancing, and expanding science-based conservation planning and technical assistance delivery to customers and partners in order to improve soil health, enhance water quality, provide wildlife habitat, and increase air quality and carbon (C) sequestration (USDA NRCS 2020g).

Research Question. In 2019 the NRCS developed conservation plans covering over 10.9 million ha (27.1 million ac) across the United States, and the 2021 budget allocates US\$729 million toward funding for CTA for further conservation planning efforts (USDA OBPA 2020). Given the centrality of conservation planning to the NRCS's work with farmers and the amount of financial resources devoted to these efforts, it is surprising that little research exists examining the relationship between having an NRCS conservation plan and the likelihood of applying conservation practices on the ground. To help fill this gap, this study analyzed data from 2015 and 2016 surveys of Iowa farmers to answer the question "What is the relationship between having an NRCS conservation plan and farmers' implementation of soil and water conservation practices?" Ten practices were selected and grouped into the following four general categories: (1) soil health, (2) nitrogen (N) management, (3) structural practices (e.g., terraces), and (4) cropland converted to perennial crops. Using a combination of prior research on BMP adoption and social-behavioral theory, we developed a statistical model to examine the relationships between having a conservation plan and practice use. Based on this body of knowledge, we hypothesize that having an NRCS conservation plan will be positively associated with the use of all 10 practices.
Conservation Planning and Practice Adoption. A single study from 1982 assessing factors affecting the use of conservation practices included having a SCS farm plan as an independent variable. This study did not find a significant relationship between having a plan and the adoption of conservation practices (Ervin and Ervin 1982). Numerous studies have researched variables associated with the adoption of conservation practices, the results of which have been summarized in several meta-analyses (Baumgart-Getz et al. 2012; Knowler and Bradshaw 2007; Liu et al. 2018; Prokopy et al. 2008, 2019; Ranjan et al. 2019). Although none of these studies have specifically looked at the relationship between having an NRCS conservation plan and the adoption of conservation practices, some analyses did indicate evidence that NRCS conservation technical assistance potentially plays a significant role in practice adoption. Both farmer participation in agency networks and access to conservation information have been shown to consistently be significant predictors of practice adoption (Baumgart-Getz et al. 2012; Knowler and Bradshaw 2007; Prokopy et al. 2008, 2019; Ranjan et al. 2019). Liu et al. (2018) highlighted several studies that found that encouraging more interpersonal contact between farmers and conservation agencies can improve conservation outreach (Lubell and Fulton 2008; Luloff et al. 2011), and that conservation practice adoption is positively correlated with frequent interactions with local conservation staff (Atwell et al. 2009; Kalcic et al. 2014; Woods et al. 2014). Studies have concluded that conservation efforts for BMP adoption should be tailored to local and/or regional locations and individuals in order to maximize effectiveness (Knowler and Bradshaw 2007; Singh et al.2018), which is one of the primary aspects of NRCS conservation planning (USDA NRCS 2006a). Conservation behavior is complex and heterogeneously motivated; therefore, studies on conservation adoption have not been able to identify many variables that consistently explain BMP adoption behavior (Reimer et al. 2014). However, there seems to be agreement that interaction with conservation professionals tends to have a positive effect on BMP adoption. Because conservation planning is a primary way that NRCS professionals interact with farmers, it seems likely that having a conservation plan would be associated with conservation practice use. 
Multiple theoretical frameworks have been applied to farmer adoption of conservation practices. Three of the most common approaches in the literature are the diffusion of innovations (Rogers 2010), the theory of planned behavior (Ajzen 1991), and the reasoned action approach (Fishbein and Ajzen 2011). Diffusion of innovations is a theory that seeks to explain the factors that influence the adoption and spread of ideas and technologies, as well as the rate that these innovations are adopted in a population (Rogers 2010). A critical aspect of innovation-diffusion theory is the role of social networks and the role of opinion leaders - members of a community who are influential in spreading information about innovations and thus have a potentially large impact on farmers gaining knowledge and awareness of a particular innovation (Rogers 2010). Although this model works well for explaining the adoption of commercial technologies like hybrid corn (Zea mays L.), researchers have criticized the diffusion of innovations for failing to posit satisfactory explanations for soil and water conservation practice adoption (Carlisle 2016) and for its inability to adequately account for the complexity of both human networks and individuals (Damanpour 1996).

The theory of planned behavior suggests that a person's attitudes and perceptions influence their behaviors (Ajzen 1991). This theoretical framework was later expanded into the reasoned action approach, which posits that an individual's decision to adopt a behavior is a function of their intention to adopt, which is in turn influenced by the individual's attitudes toward the behavior, perceived norms, and perceived behavioral control. These three drivers are themselves influenced by the individual's beliefs, which stem from a variety of background factors (depending on the situation) (Fishbein and Ajzen 2011).

Reimer et al. (2012) took a novel approach to this framework by combining the reasoned action approach with the diffusion of innovations. Specifically, Reimer et al. included five perceived practice characteristics outlined by Rogers (2010) — relative advantage, complexity, compatibility, observability, trialability-and added a sixth characteristic, risk. One of the findings of this study was that outreach efforts by conservation professionals to farmers, along with education involving the risks and benefits of BMPs (involving potential effects on profitabil- ity, yield, return on initial investment, etc.), had a significant positive effect on practice adoption (Reimer et al. 2012). The implications of this theoretical framework suggest that NRCS conservation plans would have a positive effect on practice use, since both outreach and communication of practice characteristics (including risks and benefits) are critical components of the NRCS planning process (USDA NRCS 2013b). Additionally, since the primary purpose of a conservation plan is to outline the steps that land managers should take to pursue soil and water conservation goals, we expect the conservation plan to have a strong positive influence on behavioral intention, and therefore practice use. This theoretical framework lends support to our hypothesis that conservation plans would be positively associated with the use of conservation practices.

\section{Materials and Methods}

Data. This study analyzed data from the 2015 and 2016 collection periods of the annual Iowa Farm and Rural Life Poll (IFRLP). The "Farm Poll" was created in 1982 as a longitudinal panel survey of Iowa farmers. The IFRLP survey was conducted by Iowa State University Sociology Extension in cooperation with the Iowa Department of Agriculture and Land Stewardship and the USDA National Agricultural Statistics Service (NASS). The 2015 survey was mailed to a statewide panel of 2,093 farmers and the 2016 survey to 2,089 Iowa farmers. Completed surveys were received from 1,159 farmers in 2015 and 1,039 farmers in 2016 , resulting in response rates of $55 \%$ and 50\%, respectively (Arbuckle 2016, 2017).

Because a number of farmers leave the IFRLP panel each year due to retirement and

\section{Table 1}

Comparison of farm characteristics: study sample (from lowa Farm and Rural Life Poll [IFRLP]) and 2017 Census of Agriculture (IFRLP 2016; USDA NASS 2019).

\begin{tabular}{lcc}
\hline Characteristic & IFRLP sample 2016 & Ag Census \\
\hline Average farm size (ha) & 183 & 144 \\
Farms with sales less than US $\$ 2,500(\%)$ & 6.6 & 29.3 \\
US $\$ 2,500$ to US $\$ 9,999(\%)$ & 7.7 & 9.2 \\
US $\$ 10,000$ to US $\$ 49,999(\%)$ & 18.6 & 13.6 \\
US $\$ 50,000$ to US $\$ 249,999(\%)$ & 36.4 & 21.2 \\
US $\$ 250,000$ to US $\$ 499,999(\%)$ & 14.2 & 10.3 \\
US $\$ 500,000$ to US $\$ 999,999(\%)$ & 8.8 & 9.2 \\
US $\$ 1$ million or more $(\%)$ & 3.5 & 7.2 \\
\hline Note: $n=792$. & &
\end{tabular}

other factors, combining two collection periods of the survey leads to a smaller sample. Our sample only included respondents from both the 2015 and 2016 survey, reducing the $n$ size from 1,039 to 792. To evaluate potential biases stemming from the reduction in sample size, we compared the farmers who were in both the 2015 and 2016 data sets $(n=792)$ to those who were only in one or the other $(n=237)$. A significant difference $(p=0.007)$ between the two collection periods was detected for 1 of the 10 dependent variables- $\mathrm{N}$ stabilizer; $34.5 \%$ of the study sample reported using the practice, compared to $27.0 \%$ of those who were not in the sample. Similarly, significant differences were found for 2 of the 13 independent variables - age and gender. Farmers in the study were slightly older $(p=0.000)$ (66 years old in the sample versus 63 years old for those not in the sample) and more likely to be male $(p=0.001)(94.2 \%$ for those in the sample and $87.9 \%$ for those not in the sample). Thus, the results of our analysis must be interpreted with these differences between the farmers who were in both surveys and those who were not in mind.

Over time, attrition among IFRLP participants has necessitated the periodic inclusion of new random samples of farmers. These samples have been drawn from the USDA NASS US Census of Agriculture list, which includes all landowners who could potentially earn US $\$ 1,000$ in agricultural income from their land, regardless of whether or not they actively farm. As new samples have been drawn from the list, some respondents who meet this USDA definition but do not consider themselves farmers have declined to participate. A comparison of Iowa statistics from the Census of Agriculture and statistics from the Farm Poll (table 1) indi- 
cates that this process has led to a sample bias toward farmers with higher cropland area. For instance, our sample of IFRLP farmers operated an average of 182.9 ha $(452 \mathrm{ac})$ in 2015, compared to 143.7 ha (355 ac) among the 2017 census population (USDA NASS 2019). A comparison of farm sales shows that $14.3 \%$ of IFRLP farmers in our sample had 2015 gross farm sales of less than US $\$ 10,000$, compared to $38.5 \%$ of the 2017 census population (USDA NASS 2019). At the other end of the sales spectrum, $62.9 \%$ of IFRLP farmers had 2015 sales greater than US $\$ 50,000$, compared to $47.9 \%$ for the 2017 census population (USDA NASS 2019). Some research efforts might view this bias toward farmers with larger farm sizes as a liability. However, for this project it is considered an asset, since large farms that generate US $\$ 100,000$ or more in gross farm sales operate $90 \%$ of cropland area (USDA NASS 2014). In this regard, larger farms would be a primary focus of conservation efforts in terms of impact because they encompass the majority of the land that could be placed under a conservation plan.

The IFRLP is a panel survey; therefore the average age of survey respondents tends to be slightly older than the average farmer. IFRLP farmers were an average of 65 years old in 2016, compared to 57 years old among the 2017 census population (USDA NASS 2019). It is important to note that the IFRLP results can only be generalized to Iowa farmers, and more particularly, Iowa farmers whose demographics fall within the range of the survey sample.

Variables in the Regression Models. We used binomial logistic regression to develop models examining the relationship between respondents having a current NRCS conservation plan and their use of conservation BMPs. Binomial logistic regression is an approach that is appropriate to use when the dependent variable is a dichotomous measure of membership in a group, which in this case would be farmers who used each practice (coded as a 1) and those who did not (coded as a 0 ). This multivariate regression technique provides an estimate of multiple predictor variables' impact on a dependent variable (Hair et al. 2010). Data were statistically analyzed using version 26 of IBM SPSS software (IBM Corp. 2019).

The dependent variables are measures of farmers' use of 10 BMPs grouped into four categories (table 2). Cover crops, no-till, and extended rotations form a "soil health practices" category. Cover crops, like oats (Avena sativa L.) and rye (Secale cereale L.), are defined as "crops grown primarily for the purpose of protecting and improving soil between periods of regular crop production" (Schnepf and Cox 2006). No-till is a tillage system in which the soil is not disturbed before planting except for (1) the injection of nutrients and (2) opening narrow strips with a coulter or disk seed-furrow during planting, and the entire residue remains on the soil's surface (Al-Kaisi et al.

\section{Table 2}

Dependent variables in the model $($ Yes $=1, \mathrm{No}=0$ ).

\begin{tabular}{|c|c|c|c|c|c|c|c|}
\hline Variable & Item & $\begin{array}{l}\text { Practice } \\
\text { used: } \\
\text { frequency } \\
\text { of total } n\end{array}$ & $\begin{array}{l}\text { Practice } \\
\text { used: } \\
\text { percentage } \\
\text { of total } n \\
\text { (\%) }\end{array}$ & \multicolumn{2}{|c|}{ Has conservation plan } & \multicolumn{2}{|c|}{$\begin{array}{l}\text { Does not have } \\
\text { conservation plan }\end{array}$} \\
\hline \multicolumn{8}{|l|}{ Soil health } \\
\hline Extended rotations & $\begin{array}{l}\text { Used extended rotations ( } 3 \text { or more } \\
\text { crops over a } 3 \text { to } 5 \text { year rotation) in } 2015\end{array}$ & 93 & 12.6 & 15.3 & 84.7 & 9.2 & 90.8 \\
\hline \multicolumn{8}{|l|}{$\mathrm{N}$ management } \\
\hline In-season N & $\begin{array}{l}\text { Used growing season } \mathrm{N} \text { application } \\
\text { (i.e., side-dress) in } 2015\end{array}$ & 193 & 26.1 & 27.1 & 72.9 & 24.7 & 75.3 \\
\hline \multicolumn{8}{|l|}{ Structural practices } \\
\hline In-field buffers & $\begin{array}{l}\text { Used in-field buffer strips (e.g., contour buffer } \\
\text { strips) to filter nutrients and sediment in } 2015\end{array}$ & 179 & 24.2 & 29.7 & 70.3 & 16.3 & 83.7 \\
\hline Riparian buffers & $\begin{array}{l}\text { Used buffers along streams or field edges to } \\
\text { filter nutrients and sediment from runoff } \\
\text { in } 2015\end{array}$ & 324 & 43.5 & 51.2 & 48.8 & 33.3 & 66.7 \\
\hline Terraces & Used terraces in 2015 & 252 & 34.1 & 45.3 & 54.7 & 18.5 & 81.5 \\
\hline $\begin{array}{l}\text { Cropland converted } \\
\text { to perennial crops }\end{array}$ & $\begin{array}{l}\text { Used cropland converted to perennial crops } \\
\text { (e.g., hay, pasture, trees) in } 2015\end{array}$ & 105 & 14.3 & 17.3 & 82.7 & 10.0 & 90.0 \\
\hline
\end{tabular}

Notes: $n=792$. MRTN $=$ maximum return to nitrogen $(\mathrm{N})$. 
2008). In the 2016 IFRLP survey, no-till was specified as "all years of rotation." Extended rotations was defined as "three or more crops over a three to five year rotation."

In-season $\mathrm{N}$ application, Maximum Return to Nitrogen (MRTN) application, and $\mathrm{N}$ stabilizer comprised the "nitrogen management" category. In-season N application (qualified in the 2016 IFRLP survey with "i.e., side-dress application" in parentheses) refers to applying fertilizer to a growing crop, as opposed to preplant application. The MRTN calculator or "Corn Nitrogen Rate Calculator" is an online tool developed through a partnership between four Midwestern universities that uses $\mathrm{N}$ and corn grain prices to calculate the $\mathrm{N}$ application rate where the economic net return is maximized (ISU 2020). This practice was specified as "Nitrogen rate based on Corn $\mathrm{N}$ rate calculator (MRTN)" in the survey. Nitrogen stabilizers or "inhibitors" are chemical products (e.g., "N-Serve") incorporated with fertilizer that help to prevent $\mathrm{N}$ losses by either (1) inhibiting the enzyme urease from converting urea into ammonium $\left(\mathrm{NH}_{4}^{+}\right)$or (2) inhibiting nitrification by killing nitrifying bacteria (White 2018).

Three major structural practices formed the "structural practices" category: in-field buffers, riparian buffers, and terraces. In-field buffers are strips of perennial vegetation and were specified in the survey as "In-field buffer strips (e.g., contour buffer strips) to filter nutrients and sediment." Riparian buffers were defined in the survey as "buffers along streams or field edges to filter nutrients and sediment from runoff.' Terraces are structural practices used to prevent rainfall runoff from accumulating and causing erosion on cropland, and they consist of ridges and channels constructed along the contour, most often in a manner parallel to the direction of field operations (Wheaton and Monke 2001).

The use of "cropland converted to perennial crops" was placed in its own category. In the 2016 IFRLP, the examples given for potential types of perennial crops were "hay, pasture, trees."

These 10 practices were chosen as BMP dependent variables based on criteria and recommendations from the Iowa Nutrient Reduction Strategy (INRS). The INRS is a collaborative framework developed to reduce $\mathrm{N}$ and phosphorus $(\mathrm{P})$ loads in Iowa's surface waters with the overall goal of reducing hypoxia in the Gulf of Mexico. The 10

Table 3

Estimated reductions in nitrate and phosphorus loss for selected conservation practices (IDALS et al. 2017).

\begin{tabular}{lll}
\hline Best management practice & Nitrate loss reduction (\%) & Phosphorus loss reduction (\%) \\
\hline Cover crops & 28 to 31 & $\mathrm{n} / \mathrm{a}$ \\
No-till & $\mathrm{n} / \mathrm{a}$ & 77 \\
Extended rotations & 42 & $\mathrm{n} / \mathrm{a}$ \\
In-season nitrogen & 7 & $\mathrm{n} / \mathrm{a}$ \\
MRTN application & 10 & $\mathrm{n} / \mathrm{a}$ \\
Nitrogen stabilizer & 9 & $\mathrm{n} / \mathrm{a}$ \\
Buffers & 91 & 58 \\
Terraces & $\mathrm{n} / \mathrm{a}$ & 90 \\
Perennial cover & 72 to 85 & 34 to 77 \\
\hline Note: MRTN = maximum return to nitrogen.
\end{tabular}

Note: MRTN = maximum return to nitrogen.

practices selected for this study were among the top practices identified by the INRS action plan to be the most effective at reducing $\mathrm{N}$ loss from fertilizer runoff and $\mathrm{P}$ loss from erosion (table 3) (IDALS et al. 2017). Although the INRS action plan did not differentiate between in-field and riparian buffers, both practices were used in this study because they are classified separately for the purposes of conservation planning (USDA NRCS 2020i).

To measure practice use, respondents from the 2016 IFRLP survey were presented with a list of practices and the following statement: "Many of the following are practices that can reduce nutrient loss into waterways. Please circle all numbers that apply about practices that you used or did not use in your farm operation in 2015." The practice variables used for the dependent variables in the models were coded categorically, with the practice not being used in 2015 coded as (0) and the practice being used in 2015 coded as (1).

In order to measure our independent variable of interest-whether or not farmers had a conservation plan-we utilized information from a set of questions about conservation planning included in the 2016 IFRLP survey. These questions were developed with NRCS staff and were preceded by the following text:

A conservation plan is a non-regulatory record of a farmer's decisions in managing the natural resources on the land. The plan can include a land use map, soils information, inventory of resources, and engineering notes - all based on the landowner's goals. Conservation planning can be viewed as an important step in managing a farm operation's natural resources. To protect natural resources, NRCS works one-on-one with landowners and operators on a voluntary basis to analyze, plan and install conservation practices to reduce soil erosion; improve soil health and air and water quality; create and restore wetlands; enhance fish and wildlife habitat; improve pasture and woodlands; and reduce flooding.

Survey respondents were asked, "Do you have a current conservation plan that was developed working with NRCS?" "Yes" answers were coded as (1) and "No" and "Don't Know" answers were coded as (0) into a categorical independent variable called "Current NRCS conservation plan."

Eight categorical independent variables (table 4) and four continuous independent variables (table 5) are included in the model as control variables. These 12 variables reflect factors identified in previous research as being associated with BMP practice adoption. Review articles of studies on conservation adoption have found that interaction with professional and agency networks (Baumgart-Getz et al. 2012; Knowler and Bradshaw 2007; Prokopy et al. 2008, 2019; Ranjan et al. 2019) and interpersonal contact with conservation professionals (Liu et al. 2018) have been frequently shown to increase the likelihood of conservation BMP adoption. As Roger Wilkinson (2011) said in his essay on the many meanings of adoption: "Adoption is not an event... [it] is not a steady state but a continuous process," and "a technology may be disadopted at any time." Farmers may reject new conservation practices even after adopting them because of incompatibility with their operations or high maintenance requirements (Swanson et 


\section{Table 4}

Categorical independent variables in the model.

\begin{tabular}{|c|c|c|c|}
\hline Variable & Item & Frequency & Percentage (\%) \\
\hline Current NRCS conservation plan & $\begin{array}{l}\text { Had a current conservation plan that was developed with NRCS } \\
\left(\text { Yes }=1, \mathrm{No}_{0}=0\right)\end{array}$ & 450 & 60.2 \\
\hline Service Center visits $(0)$ & $\begin{array}{l}\text { Number of times since spring } 2013 \text { visited a USDA Service Center specifically } \\
\text { for assistance with conservation (No visits) }\end{array}$ & 286 & 44.1 \\
\hline Service Center visits ( 1 to 2 ) & $\begin{array}{l}\text { Number of times since spring } 2013 \text { visited a USDA Service Center specifically } \\
\text { for assistance with conservation ( } 1 \text { to } 2 \text { visits) }\end{array}$ & 148 & 22.8 \\
\hline Service Center visits (3 to 4 ) & $\begin{array}{l}\text { Number of times since spring } 2013 \text { visited a USDA Service Center specifically } \\
\text { for assistance with conservation ( } 3 \text { to } 4 \text { visits) }\end{array}$ & 91 & 14.0 \\
\hline Service Center visits ( 5 or more) & $\begin{array}{l}\text { Number of times since spring } 2013 \text { visited a USDA Service Center specifically } \\
\text { for assistance with conservation ( } 5 \text { to } 40 \text { visits) }\end{array}$ & 123 & 19.0 \\
\hline Livestock & Had livestock on farm operation as of January 1, 2016 (Yes = 1, No = 0) & 329 & 41.5 \\
\hline Pasture and hay & Managed pasture and/or hay in 2015 (Yes = 1, No = 0) & 385 & 48.6 \\
\hline Conservation Reserve Program & $\begin{array}{l}\text { Managed acreage enrolled in the Conservation Reserve Program in } 2015 \\
(\text { Yes }=1, \text { No }=0)\end{array}$ & 306 & 38.6 \\
\hline Crop insurance & Purchased crop insurance in 2015 (Yes = 1, No = 0) & 545 & 72.7 \\
\hline Highly erodible land & $\begin{array}{l}\text { Farmed any land in } 2015 \text { that is considered to be highly erodible (HEL) } \\
(\text { Yes }=1, \text { No = 0) }\end{array}$ & 373 & 49.2 \\
\hline $\begin{array}{l}\text { Gross farm income (low-sales small } \\
\text { family farm) }\end{array}$ & 2015 gross farm sales between US\$0 and US\$149,999 & 441 & 58.2 \\
\hline $\begin{array}{l}\text { Gross farm income (moderate-sales } \\
\text { small family farm) }\end{array}$ & 2015 gross farm sales between US\$150,000 and US\$349,000 & 175 & 23.1 \\
\hline $\begin{array}{l}\text { Gross farm income (mid-size } \\
\text { family farm) }\end{array}$ & 2015 gross farm sales between US\$350,000 and US\$999,999 & 114 & 15.0 \\
\hline $\begin{array}{l}\text { Gross farm income (large-scale } \\
\text { family farm) }\end{array}$ & 2015 gross farm sales US\$1,000,000 or more & 28 & 3.7 \\
\hline Gender & Self-reported gender of farmer $($ Male $=1$, Female $=0)$ & 725 & 94.6 \\
\hline
\end{tabular}

Notes: $n=792$. NRCS $=$ USDA Natural Resources Conservation Service.

al. 1986). Conservation adoption is a process that takes place over time and has been found to be associated with farmer contact with conservation agency professionals, therefore we wanted to control for the extent that farmers had networked with NRCS employees over time in our model predicting practice use. The 2016 Farm Poll included the following question: "About how many times since spring 2013 have you visited a USDA Service Center specifically for assis- tance with conservation?” Respondents were able to write in the amount of estimated visits, which ranged from 0 to 40 . As a continuous variable, the distribution for the responses to this question was highly skewed, so the data were transformed into a categorical variable based on quartiles to achieve a normal distribution. Zero visits were coded as (0); one to two visits were coded as (1); three to four visits were coded as (2); and five or greater visits were coded as (3).
We include a multidimensional scale measure of stewardship motivations. Review articles of the BMP literature have also noted that "stewardship" motivation, ethic, or identity have been found by many studies to be positively associated with conservation adoption (Prokopy et al. 2019; Ranjan et al. 2019). The 2015 IFRLP survey contained a section about factors related to farmer decisions about soil and water conservation. A series

Table 5

Continuous independent variables in the model.

\begin{tabular}{|c|c|c|c|c|c|}
\hline Variable & Item & Mean & Standard deviation & Minimum & Maximum \\
\hline Percentage field cropland rented & Percentage of field cropland rented in 2015 (\%) & 29.22 & 35.77 & 0.00 & 100.00 \\
\hline Age & Age of farmer (in years) in 2016 & 65.83 & 10.23 & 18.00 & 94.00 \\
\hline
\end{tabular}

Note: $n=792$ 
of 23 statements measuring potential motivations were preceded by the following text:

The following are some factors related to decisions about soil and water conservation. Thinking in general about the conservation practices that you have used in your farm operation over the years, please rate how important the following factors have been in decisions to incorporate conservation practices into your operation.

Respondents could rate the importance of each factor on a 5-point scale ranging from "not at all important" to "very important." We conducted a factor analysis and identified a "stewardship motive" factor among 11 items, which were combined into a scale. All factor loadings were above 0.5 , indicating that the items loaded well together, and reliability analysis resulted in a Cronbach's alpha of 0.924 , indicating a strong relationship between the items in this scale. Items included motivational factors such as "Protect the land for the next generation" and "Avoid polluting streams, rivers, and lakes." A summated scale continuous variable called "Stewardship Motive" was created using this scale, ranging in values from one to five, with a value of one reflecting low stewardship motivation and five reflecting high motivation. This variable was included in the model to control for the influence of stewardship motivations on the use of conservation practices.

Farm characteristics that have been found in multiple studies to be significantly associated with conservation adoption include having livestock, pasture and hay land, land vulnerable to erosion, total field cropland, percentage of field cropland rented, and gross farm income (Baumgart-Getz et al. 2012; Knowler and Bradshaw 2007; Liu et al. 2018; Prokopy et al. 2008, 2019; Ranjan et al. 2019). Thus, these items were included in the model as control variables, as were farmer characteristics such as participation in government financial programs (in our study, the CRP), purchasing crop insurance, age, and gender (Baumgart-Getz et al. 2012; Knowler and Bradshaw 2007; Liu et al. 2018; Prokopy et al. 2008, 2019; Ranjan et al. 2019). A measure of farmer use of land classified by the USDA as HEL was particularly relevant to our study because all farmers who plant row crops on HEL are required to have a conservation plan if they want to access most USDA benefit programs (Claassen 2004).

\section{Results and Discussion}

Descriptive Statistics. The descriptive statistics for the 10 dependent variables in the model are presented in table 2 . For any given practice, the majority of farmers reported not having used the practice in 2015. The most widely used soil health conservation practice in the sample was no-till at $37.7 \%$, and the most common $\mathrm{N}$ management practice used was $\mathrm{N}$ stabilizer at $36.8 \%$. The most widely used structural practice (and overall practice) was riparian buffers at $43.5 \%$. The least commonly adopted practice overall was the use of extended crop rotations at $12.6 \%$. Data were also presented on the percentages of participants that used or did not use each practice in either the presence or absence of an NRCS conservation plan. Farmers who had a conservation plan reported higher percentages of practice use for each of the nine dependent variable practices than farmers who did not have a plan.

Independent Variables. The descriptive statistics for the categorical independent variables in the model are presented in table 4 . The majority of survey respondents (60.2\%) reported having a current NRCS conservation plan. Nearly half (44.1\%) reported not having visited a USDA Service Center for conservation assistance during the past two years (spring of 2013 to spring of 2015), compared to $22.8 \%$ visiting 1 to 2 times, $14.0 \%$ visiting 3 to 4 times, and $19.0 \%$ visiting 5 to 40 times. Farmers visited their local Service Center for conservation an average of 2.5 times during the previous three years. Livestock were a part of $41.5 \%$ of farmers' operations, and just under half (48.6\%) reported managing hay or pasture. Among respondents, 38.5\% reported managing land enrolled in the CRP. A majority of respondents $(72.7 \%)$ reported having crop insurance. Roughly half of respondents (49.2\%) reported farming HEL. In terms of gross farm income, over half (58.2\%) fell into the low-sales small farm category, while $23.1 \%$ were in the moderate-sales small farm category. Among respondents, 15\% fell into the mid-size farm category, and 3.7\% managed large farms. Nearly all of the respondents (94.6\%) were male.

The descriptive statistics for continuous independent variables in the model are presented in table 5 . The mean stewardship motive score was 3.79 on a scale from 1.00 to 5.00. Respondents farmed an average of 156.59 ha $(386.93 \mathrm{ac})$ of field crops, and on average, $29.22 \%$ of field cropland was rented. The average age of the respondents was 65 years, with the youngest being 18 and the oldest being 94 years old.

Regression Results. All assumptions of binary logistic regression were examined to determine if the model was appropriate for testing our hypothesis. The assumption of independence of errors was tested to ensure that the observed variance was in the expected range for the model. Dividing the chi-square statistic from each model's Hosmer and Lemeshow "goodness of fit" test by its degrees of freedom produced ratios well within acceptable ranges (Field 2009). Linearity of the continuous variables with respect to the logit of the dependent variable was assessed using the Box-Tidwell procedure (Box and Tidwell 1962). A Bonferroni correction was applied using all 14 terms in each model (Tabachnick and Fidell 2014), resulting in statistical significance being acceptable for all models using an alpha level of $p<0.003$. All continuous independent variables were found to be linearly related to the logit of the dependent variable based on this assessment. We ran diagnostics on each model to assess any issues with multicollinearity. All tolerance values were greater than 0.1 (Menard 2002), and all variance inflation factor (VIF) values were less than 10 (Myers 1990). Additionally, no two variance proportions were greater than 0.9 for any of the predictors in any of the models (Hair et al. 2013). These results indicated no issues with multicollinearity.

In tables 6 through 9, we have reported the logistic regression coefficients (B), the standard error of the coefficients (SE), and the odds ratios of the coefficients (Exp[B]), with statistical significance of variables in the model indicated with asterisks as noted on the coefficients. The strength and direction of the relationships between each of the dependent variables and the predictor variables are indicated by the odds ratios, with positive associations being designated by values greater than one and negative associations being designated by values of less than one (Hair et al. 2010).

Conservation Plans and Soil Health Practices. The regression results for cover crops, no-till, and extended rotations are summarized in table 6. Listwise deletion of cases with missing values reduced the sample size from 792 to 481 for cover crops and no-till and to 476 for extended rotations. 
Table 6

Logistic regression results: used the soil health practice in 2015 (Yes $=1$, No $=0$ ).

\begin{tabular}{|c|c|c|c|c|c|c|c|c|c|}
\hline \multirow[b]{2}{*}{ Predictor variables } & \multicolumn{3}{|l|}{ Cover crops } & \multicolumn{3}{|l|}{ No-till } & \multicolumn{3}{|c|}{ Extended rotations } \\
\hline & B & SE & $\operatorname{Exp}(B)$ & B & SE & $\operatorname{Exp}(B)$ & B & SE & $\operatorname{Exp}(B)$ \\
\hline Constant & $-3.208 *$ & 1.503 & 0.040 & $-6.014 * * *$ & 1.512 & 0.002 & -2.758 & 1.673 & 0.063 \\
\hline Service Center visits (1 to 2 ) & 0.364 & 0.396 & 1.439 & 0.051 & 0.290 & 1.052 & -0.343 & 0.432 & 0.710 \\
\hline Service Center visits (3 to 4 ) & 0.745 & 0.438 & 2.107 & 0.089 & 0.349 & 1.093 & 0.315 & 0.460 & 1.370 \\
\hline Livestock $($ Yes = 1) & $0.754 * *$ & 0.290 & 2.126 & 0.073 & 0.236 & 1.076 & 0.447 & 0.339 & 1.564 \\
\hline Pasture and hay $($ Yes $=1)$ & 0.433 & 0.286 & 1.542 & -0.224 & 0.235 & 0.800 & $0.933 * *$ & 0.353 & 2.543 \\
\hline Conservation Reserve Program (Yes $=1$ ) & 0.445 & 0.274 & 1.561 & -0.396 & 0.235 & 0.673 & -0.105 & 0.328 & 0.901 \\
\hline Crop insurance $(Y e s=1)$ & -0.273 & 0.432 & 0.761 & -0.136 & 0.322 & 0.873 & 0.177 & 0.461 & 1.194 \\
\hline Highly erodible land $(Y e s=1)$ & 0.123 & 0.304 & 1.131 & $0.926 * * *$ & 0.241 & 2.525 & 0.296 & 0.350 & 1.345 \\
\hline Gross farm income (mid-size family farm) & $1.313 * *$ & 0.459 & 3.717 & -0.122 & 0.367 & 0.885 & -0.574 & 0.560 & 0.563 \\
\hline Gross farm income (large-scale family farm) & $1.657 * *$ & 0.642 & 5.244 & -0.269 & 0.575 & 0.764 & 0.162 & 0.744 & 1.175 \\
\hline Age & 0.002 & 0.014 & 1.002 & 0.005 & 0.011 & 1.006 & 0.004 & 0.015 & 1.004 \\
\hline Gender (Male = 1) & -0.553 & 0.746 & 0.575 & $2.263 *$ & 1.060 & 9.611 & $-1.922 * *$ & 0.652 & 0.146 \\
\hline $\bar{n}$ & 481 & & & 481 & & & 476 & & \\
\hline Nagelkerke $R^{2}$ & 0.246 & & & 0.221 & & & 0.14 & & \\
\hline Percentage correctly classified (\%) & 80.2 & & & 71.3 & & & 87.4 & & \\
\hline Hosmer and Lemeshow & $p=0.519$ & & & $p=0.192$ & & & $p=0.874$ & & \\
\hline Model $X^{2}$, df 17 & $81.213 * * *$ & & & $86.190 * * *$ & & & $37.054 * *$ & & \\
\hline
\end{tabular}

$* p<0.05, * * p<0.01, * * * p<0.001$

Notes: NRCS $=$ USDA Natural Resources Conservation Service. $B=$ logistic regression coefficients. Exp $(B)=$ odds ratios of the coefficients.

None of the Hosmer and Lemshow test statistics were significant at $p<0.05$, indicating a good model fit for all three models. The likelihood ratio chi-square test statistics were all significant at $p<0.01$ or lower, indicating overall significance of the models. The percentages correctly classified by the models ranged from $71.3 \%$ to $87.4 \%$, indicating adequate predictive accuracy.

Contrary to our expectations, having an NRCS conservation plan was significantly associated with only one of the three practices in the soil health category, no-till, with the predicted odds of a farmer with a conservation plan using no-till being 1.712 times higher than a farmer without a plan (table 6). However, the number of times the respondent had visited a USDA Service Center for assistance with conservation in the previous three years was significantly associated with the use of both cover crops and no-till. Specifically, the predicted odds of a farmer using cover crops was 3.938 times higher for those who visited a Service Center five times or more in the previous three years versus those who had not visited a Service Center for conservation assistance during that time. The predicted odds of a farmer using no-till was 1.603 times higher for those who visited a Service Center five or more times versus those who did not visit a Service Center. Stewardship motive was also a positive predictor of the use of no-till (table 6). Owning livestock was a significant predictor of the use of cover crops, which seems reasonable since cover crops are often used as forage for livestock. There was also a positive relationship between gross farm income (GFI) and the use of cover crops, which may be because farmers with higher GFI have more disposable income to invest in cover crops. These two findings align with previous research on cover crop adoption (Arbuckle and RoeschMcNally 2015). Managing pasture and hay was significantly associated with the use of extended rotations. This makes sense because many extended rotations include forage or hay crops such as alfalfa (Medicago sativa
L.) as one of the crops. Farming HEL was associated with the use of no-till farming, which is a common practice on HEL fields. Interestingly, gender was significant in the use of no-till and extended rotations, with male farmers being much more likely than female farmers to use no-till and the opposite being true for extended rotations. However, this finding should be interpreted with caution, since the vast majority of farmers in the sample $(94.6 \%)$ were male.

Conservation Plans and Nitrogen Management Practices. The regression results for in-season N, MRTN application, and N stabilizer are summarized in table 7 . Listwise deletion of cases with missing values reduced the sample sizes from 792 to 478, 472, and 476 , respectively. None of the Hosmer and Lemshow test statistics were significant at $p$ $<0.05$, indicating a good model fit for all three models. The likelihood ratio chi-square test statistics were all significant at $p<0.05$ or lower, indicating overall significance of the models. The percentages correctly classified 
Table 7

Logistic regression results: used the nitrogen management practice in 2015 (Yes $=1$, No $=0$ ).

\begin{tabular}{|c|c|c|c|c|c|c|c|c|c|}
\hline \multirow[b]{2}{*}{ Predictor variables } & \multicolumn{3}{|c|}{ In-season nitrogen } & \multicolumn{3}{|c|}{ MRTN application } & \multicolumn{3}{|c|}{ Nitrogen stabilizer } \\
\hline & B & SE & $\operatorname{Exp}(B)$ & B & SE & $\operatorname{Exp}(B)$ & B & SE & $\operatorname{Exp}(B)$ \\
\hline Constant & -2.324 & 1.292 & 0.098 & $-4.464 * *$ & 1.551 & 0.012 & $-3.504 * *$ & 1.342 & 0.030 \\
\hline Service Center visits ( 1 to 2 ) & -0.173 & 0.320 & 0.841 & 0.424 & 0.346 & 1.527 & 0.501 & 0.295 & 1.651 \\
\hline Service Center visits ( 3 to 4 ) & 0.536 & 0.358 & 1.710 & 0.172 & 0.435 & 1.187 & $0.798 *$ & 0.359 & 2.222 \\
\hline Livestock (Yes = 1) & $0.626 *$ & 0.249 & 1.870 & $0.562 *$ & 0.284 & 1.754 & 0.004 & 0.240 & 1.004 \\
\hline Pasture and hay $($ Yes $=1)$ & -0.239 & 0.248 & 0.787 & -0.363 & 0.284 & 0.696 & 0.012 & 0.239 & 1.012 \\
\hline Conservation Reserve Program (Yes $=1$ ) & 0.112 & 0.241 & 1.118 & 0.008 & 0.276 & 1.008 & -0.276 & 0.238 & 0.759 \\
\hline Crop insurance $($ Yes = 1) & 0.233 & 0.357 & 1.262 & 0.277 & 0.443 & 1.319 & $1.016 * *$ & 0.380 & 2.762 \\
\hline Highly erodible land (Yes = 1) & -0.326 & 0.259 & 0.722 & 0.146 & 0.300 & 1.157 & -0.089 & 0.250 & 0.915 \\
\hline Gross farm income (mid-size family farm) & 0.196 & 0.378 & 1.216 & 0.253 & 0.422 & 1.288 & 0.706 & 0.375 & 2.025 \\
\hline Gross farm income (large-scale family farm) & 0.928 & 0.577 & 2.529 & -0.267 & 0.671 & 0.765 & -0.415 & 0.572 & 0.660 \\
\hline Age & 0.007 & 0.012 & 1.007 & -0.005 & 0.013 & 0.995 & -0.002 & 0.011 & 0.998 \\
\hline Gender & -0.595 & 0.609 & 0.552 & -0.663 & 0.714 & 0.515 & -0.429 & 0.659 & 0.651 \\
\hline$n$ & 478 & & & 472 & & & 476 & & \\
\hline Nagelkerke $R^{2}$ & 0.107 & & & 0.108 & & & 0.230 & & \\
\hline Percentage correctly classified (\%) & 72.8 & & & 81.8 & & & 67.6 & & \\
\hline Hosmer and Lemeshow & $p=0.608$ & & & $p=0.386$ & & & $p=0.824$ & & \\
\hline Model $X^{2}, d f 17$ & $37.132 * *$ & & & $32.67 *$ & & & $89.323 * * *$ & & \\
\hline
\end{tabular}

${ }^{*} p<0.05, * * p<0.01, * * * p<0.001$

Notes: NRCS $=$ USDA Natural Resources Conservation Service. MRTN $=$ maximum return to nitrogen. $B=$ logistic regression coefficients. Exp $(B)=$ odds ratios of the coefficients.

by the models ranged from $67.63 \%$ to $81.8 \%$, indicating adequate predictive accuracy.

Contrary to our hypothesis, having an NRCS conservation plan was not significantly associated with any of the three $\mathrm{N}$ management practices (table 7). However, visiting a USDA Service Center for conservation assistance was significantly associated with the use of $\mathrm{N}$ stabilizer. Specifically, the predicted odds of a farmer using this practice was 2.222 times higher for those who visited a Service Center three to four times in the previous three years versus those who had not visited a Service Center during that time, and the predicted odds of use were 2.206 times higher for those who visited a Service Center five times or more versus those who did not visit a Service Center.

Additionally, having livestock was positively associated with the use of both in-season $\mathrm{N}$ and MRTN application, and the amount of field cropland and the purchase of crop insurance were positively associ- ated with the use of $\mathrm{N}$ stabilizer (table 7). Stewardship motive was positively associated with MRTN application.

Conservation Plans and Structural Practices. The regression results for in-field buffers, riparian buffers, and terraces are summarized in table 8. Listwise deletion of cases with missing values reduced the sample size from 792 to 478 for in-field buffers and riparian buffers and 472 for extended rotations. None of the Hosmer and Lemshow test statistics were significant at $p<0.05$, indicating a good model fit for all three models. The likelihood ratio chi-square test statistics were all significant at $p<0.001$, indicating overall significance of the models. The percentages correctly classified by the models ranged from $69.9 \%$ to $74.7 \%$, indicating adequate predictive accuracy.

In the structural practices category, terraces was the only practice that was found to have a statistically significant relationship with having a current NRCS conservation plan, with the predicted odds of a farmer with a conservation plan using terraces being 2.170 times higher than a farmer without a plan (table 8). Terraces are one of the most common practices the NRCS assists farmers with on cropland, so this finding is not surprising, even though the lack of a relationship between conservation planning and the other two structural practices was unexpected.Visiting a USDA Service Center for conservation assistance was significantly associated with practice use. For the use of in-field buffers, the predicted odds of a farmer using this practice were 2.247 times higher for those who visited a Service Center three to four times in the previous three years and 2.075 times higher for those who visited a Service Center five or more times versus those who had not visited a Service Center during that time. Service Center visits were also significantly associated with the use of terraces, with the predicted odds of a farmer using this practice being 1.951 times higher 
Table 8

Logistic regression results: used the structural practice in 2015 (Yes $=1$, No $=0$ ).

\begin{tabular}{|c|c|c|c|c|c|c|c|c|c|}
\hline \multirow[b]{2}{*}{ Predictor variables } & \multicolumn{3}{|c|}{ In-field buffers } & \multicolumn{3}{|c|}{ Riparian buffers } & \multicolumn{3}{|l|}{ Terraces } \\
\hline & B & SE & $\operatorname{Exp}(B)$ & B & SE & $\operatorname{Exp}(B)$ & B & SE & $\operatorname{Exp}(B)$ \\
\hline Constant & $-2.725 *$ & 1.347 & 0.066 & $-3.281 * *$ & 1.256 & 0.038 & $-7.249 * * *$ & 1.607 & 0.001 \\
\hline Service Center visits (1 to 2 ) & 0.231 & 0.330 & 1.259 & -0.069 & 0.284 & 0.934 & $0.668 *$ & 0.296 & 1.951 \\
\hline Service Center visits (3 to 4 ) & $0.810 *$ & 0.368 & 2.247 & 0.636 & 0.347 & 1.889 & 0.412 & 0.361 & 1.510 \\
\hline Livestock (Yes = 1) & 0.196 & 0.260 & 1.216 & -0.126 & 0.237 & 0.882 & $0.579 *$ & 0.250 & 1.784 \\
\hline Pasture and hay $($ Yes $=1)$ & 0.132 & 0.258 & 1.141 & 0.061 & 0.236 & 1.063 & $-0.554 *$ & 0.252 & 0.574 \\
\hline Conservation Reserve Program $($ Yes $=1$ ) & $0.598 *$ & 0.246 & 1.819 & $1.090 * * *$ & 0.226 & 2.976 & -0.353 & 0.245 & 0.702 \\
\hline Crop insurance $($ Yes $=1)$ & -0.423 & 0.355 & 0.655 & -0.506 & 0.319 & 0.603 & -0.436 & 0.342 & 0.647 \\
\hline Highly erodible land $(Y e s=1)$ & $0.625 *$ & 0.271 & 1.869 & -0.126 & 0.247 & 0.882 & $0.689 * *$ & 0.255 & 1.991 \\
\hline Gross farm income (mid-size family farm) & -0.041 & 0.393 & 0.960 & 0.289 & 0.361 & 1.335 & 0.345 & 0.380 & 1.412 \\
\hline Gross farm income (large-scale family farm) & -1.081 & 0.663 & 0.339 & 0.029 & 0.588 & 1.029 & -0.114 & 0.594 & 0.892 \\
\hline Age & 0.004 & 0.012 & 1.004 & 0.009 & 0.011 & 1.009 & 0.023 & 0.012 & 1.024 \\
\hline Gender & -1.173 & 0.600 & 0.310 & -0.504 & 0.618 & 0.604 & 1.763 & 1.064 & 5.827 \\
\hline$n$ & \multicolumn{3}{|l|}{478} & \multicolumn{3}{|l|}{478} & \multicolumn{3}{|l|}{472} \\
\hline Nagelkerke $R^{2}$ & \multicolumn{3}{|l|}{0.155} & \multicolumn{3}{|l|}{0.224} & \multicolumn{3}{|l|}{0.271} \\
\hline Percentage correctly classified (\%) & \multicolumn{3}{|l|}{74.7} & \multicolumn{3}{|l|}{69.9} & \multicolumn{3}{|l|}{71.8} \\
\hline Hosmer and Lemeshow & \multicolumn{3}{|c|}{$p=0.595$} & \multicolumn{3}{|l|}{$p=0.369$} & \multicolumn{3}{|l|}{$p=0.513$} \\
\hline Model $X^{2}, d f 17$ & \multicolumn{3}{|c|}{$52.889 * * *$} & \multicolumn{3}{|l|}{$87.832 * * *$} & \multicolumn{3}{|c|}{$104.250 * * *$} \\
\hline
\end{tabular}

$* p<0.05, * * p<0.01, * * * p<0.001$

Notes: NRCS $=$ USDA Natural Resources Conservation Service. $B=$ logistic regression coefficients. $\operatorname{Exp}(B)=$ odds ratios of the coefficients.

for those who visited a Service Center one to two times in the previous two years and 2.902 times higher for those who visited a Service Center five or more times versus those who had not visited a Service Center during that time.

Having pasture and/or hay was negatively associated with the use of in-field buffers (table 8), perhaps because in-field buffers are primarily used on cropland. Farming HEL fields was positively associated with terrace use, which makes sense because terraces are a common practice on land with high erosion potential. Having livestock was also positively associated with terrace use. Managing land enrolled in the CRP was positively associated with the use of both in-field buffers and riparian buffers. This finding makes sense considering that both of these practices are the common structural practices involved in CRP contracts.

Conservation Plans and Cropland Converted to Perennial Crops. The regression results for use of cropland converted to peren- nial crops are summarized in table 9. Listwise deletion of cases with missing values reduced the sample size from 792 to 468. The Hosmer and Lemshow test statistic was not significant $(p=0.627)$, indicating a good model fit. The likelihood ratio chi-square test statistic was significant at $p<0.001$, indicating overall significance of the model. The percentage correctly classified by the model was $88.5 \%$, indicating adequate predictive accuracy.

Contrary to our hypothesis, the use of cropland converted to perennial crops was not significantly associated with having a current NRCS conservation plan; however, it was positively associated with USDA Service Center visits for conservation assistance (table 9). The predicted odds of a farmer using converted land was 2.858 times higher for those who visited a Service Center for conservation assistance five or more times in the previous three years versus those who had not visited a Service Center during that time. The use of converted cropland was also significantly associated with managing both pasture and hay land and land enrolled in CRP. This finding makes sense due to the fact that pasture, hay, and CRP land are all associated with perennial vegetation.

\section{Summary and Conclusions}

Although the results of our research did not fully align with our hypothesis, the results have substantial import for the soil and water conservation community. While having an NRCS conservation plan was not a significant predictor of farmer practice use for all but two of the selected conservation BMPs, farmers' visits to a USDA Service Center, specifically for conservation assistance, was the most consistent significant predictor of practice use. This finding seems to indicate that the conservation plan itself is not what encourages practice use, but rather it is farmers interacting with NRCS conservation professionals face-to-face over time that is associated with the use of conservation practices. This result aligns with other research that has found that interaction with profes- 


\section{Table 9}

Logistic regression results: used cropland converted to perennial crops in 2015 (Yes = 1, No = 0).

\begin{tabular}{|c|c|c|c|}
\hline Predictor variables & B & SE & $\operatorname{Exp}(B)$ \\
\hline Constant & -3.401 & 1.811 & 0.033 \\
\hline Current NRCS conservation plan (Yes = 1) & -0.053 & 0.434 & 0.948 \\
\hline Service Center visits (1 to 2 ) & 0.473 & 0.495 & 1.605 \\
\hline Service Center visits (3 to 4 ) & 0.976 & 0.520 & 2.655 \\
\hline Service Center visits (5 or more) & $1.050 *$ & 0.505 & 2.858 \\
\hline Stewardship motive & 0.150 & 0.263 & 1.162 \\
\hline Livestock (Yes = 1) & 0.606 & 0.360 & 1.833 \\
\hline Pasture and hay (Yes = 1) & $1.268 * * *$ & 0.396 & 3.554 \\
\hline Conservation Reserve Program (Yes = 1) & $0.873 * *$ & 0.341 & 2.395 \\
\hline Crop insurance $($ Yes = 1) & -0.525 & 0.488 & 0.591 \\
\hline Highly erodible land (Yes = 1) & 0.476 & 0.382 & 1.609 \\
\hline All field cropland (log10 transformation) & 0.187 & 0.421 & 1.205 \\
\hline Percentage field cropland rented & -0.246 & 0.517 & 0.782 \\
\hline Gross farm income (moderate sales small family farm) & -0.213 & 0.462 & 0.808 \\
\hline Gross farm income (mid-size family farm) & -0.109 & 0.553 & 0.897 \\
\hline Gross farm income (large-scale family farm) & -1.010 & 0.932 & 0.364 \\
\hline Age & -0.004 & 0.017 & 0.996 \\
\hline Gender & -1.155 & 0.821 & 0.315 \\
\hline $\bar{n}$ & 468 & & \\
\hline Nagelkerke $R^{2}$ & 0.237 & & \\
\hline Percentage correctly classified & $88.5 \%$ & & \\
\hline Hosmer and Lemeshow & $p=0.627$ & & \\
\hline Model $X^{2}, d f 17$ & $60.951 * * *$ & & \\
\hline
\end{tabular}

$* p<0.05, * * p<0.01, * * * p<0.001$

Notes: NRCS = USDA Natural Resources Conservation Service. $B=$ logistic regression coeffi-

cients. $\operatorname{Exp}(B)=$ odds ratios of the coefficients.

sional and agency networks (Baumgart-Getz et al. 2012; Knowler and Bradshaw 2007; Prokopy et al. 2008, 2019; Ranjan et al. 2019; Reimer et al. 2012) and frequent interaction with conservation professionals (Liu et al. 2018) often increases the likelihood of conservation BMP adoption.

This suggests that NRCS employees should increase efforts to develop networking relationships with farmers. In particular, employees should encourage multiple faceto-face interactions over time through office and field visits, which may build trust and confidence with the farmer. This in turn might serve to encourage and support adoption and continued use of conservation BMPs. As Osmond et al. (2012) note, “Technical assistance to farmers is most effective when delivered by a trusted local contact... and is highly people intensive." Lobry de Bruyn et al. (2017) suggest that NRCS personnel facilitate peer-to-peer interactions among farmers along with agency employees through conservation discussion events such as farmer-led mini-workshops called "shop talks" or more traditional high-attendance workshops with a combination of farmers and agency employees as speakers.

While having an NRCS conservation plan was a significant predictor of using no-till farming and terraces as conservation BMPs, no such relationship was found with the other eight BMPs. We believe that this lack of significance could be due in part to the age of the conservation plans. Although we did not ask farmers about when their plans were established, it is likely that a large proportion of plans are compliance-related HEL management plans. These plans would have been developed in the late 1980s and early 1990s as a response to compliance measures of the 1985 Farm Bill (Helms 2005), which stipulated that all farms with HEL cropland or wetlands establish a conservation plan (Malone 1985). Such plans were not the whole-farm resource management plans that are standard today, and usually only included a small number of required practices on one to a few fields on the farm (Claassen 2004). That no distinction was made in the survey questions between whole-farm conservation plans and HEL or similar plans represents a significant limitation. That being said, we were able to control for having HEL fields in our regression model. While having HEL was a significant predictor of the use of no-till, in-field buffers, and terraces, having a conservation plan was still a significant predictor of the use of no-till and terraces even after controlling for HEL, and the number of Service Center visits was a significant predictor of all three practices, after controlling for both HEL and conservation plans. Since it is reasonable to assume that most HEL fields have an HEL conservation plan due to conservation compliance regulations (Malone 1985), the regression results would seem to suggest that conservation plans in general, along with technical assistance, are important factors associated with adoption of these practices regardless of the presence of an HEL plan. Nevertheless, future research would benefit from collection of more detailed data on the age and nature of the conservation plans, for example whether the plan is an HEL or wetland plan or a whole-farm conservation plan.

Additionally, the NRCS's current soil health initiative, "Unlock the Secrets of the Soil," was not initiated until 2012 (USDA NRCS 2012). Therefore, it may be the case that the push for including practices like cover crops in conservation plans was largely not occurring until after this date, which may not have been reflected in the 2016 survey results. Similarly, NRCS's push for improved conservation planning in association with the NCPP was not developed until 2015 (NACD 2017). Future research could examine whether or not these initiatives have had an impact on the planning process and practice use in the years following their establishment.

Another limitation is related to our conservation social networking measure. The 2016 IFRLP survey only asked about farmer visits to a USDA Service Center for conservation assistance. The survey did not ask about the specific nature of the visits (e.g., visits to discuss practices under contract and visits for noncontract technical assistance), and the survey also did not measure NRCS employee visits to farms. Field visits with farmers are a significant part of the planning process and the work that NRCS employees do, and this should be considered in future research. Furthermore, this question on the survey only asked about NRCS interactions during the previous three years rather than 
measuring interactions over the long term. It may also be the case that there are characteristic differences between people who are motivated to choose to contact their local USDA Service Center for conservation assistance and those who do not. While our regression model did control for stewardship motive and several farmer demographics, future research might benefit from examining other farmer characteristics that could potentially influence a farmer to voluntarily contact the NRCS.

It would also be of interest to ask if farmers with a conservation plan developed that plan through an NRCS financial incentive program, since obtaining financial assistance has been shown to be a primary driver of practice adoption (Claassen and Duquette 2012; Reimer and Prokopy 2014). While conservation plans are independent from USDA contracts for financial assistance, conservation plans are often a precursor to applying for a program contract (USDA NRCS 2016b). Additionally, programs such as EQIP, CRP, and CSP require technical assistance during the practice implementation phase of the contract, and long-term technical assistance is required to assist with enhancement activities in the CSP program (Lobry de Bruyn and Andrews 2016). We were able to control for participation in the CRP in our regression model, and our findings indicate that CRP participation was a significant predictor of the use of riparian buffers and in-field buffers. While having a conservation plan was not a significant predictor of the use of either of these practices, the number of service center visits was significant for the use of in-field buffers, even after controlling for participation in CRP. This indicates that, at least in this case, technical assistance is still a key element associated with practice adoption, regardless of program participation. This is important considering that conservation agency social capital and capacity (in the form of labor, knowledge, and time) for technical assistance and outreach is decreasing due to workforce retirements, downsizing, and consolidation (Lobry de Bruyn et al. 2017).

Although this study did not find consistent statistically significant relationships between conservation plans and BMP use, assisting farmers with their conservation needs-whether in the field or in the office-continues to be an integral part of the overall planning process funded through the national CTA program and other programs. This study provides evidence that conservation professionals delivering conservation technical assistance to farmers through multiple interactions over time is strongly associated with farmer use of conservation BMPs. NRCS employees can use this information to inform ways to improve farmer practice adoption, particularly by exploring opportunities to encourage and foster long-term relationships through technical assistance with farmers. Supporting farmers in this way can in turn support NRCS's goal of "getting conservation on the ground."

\section{Acknowledgements}

This research was supported by the C-CHANGE Iowa State University Presidential Interdisciplinary Research Initiative and by the Iowa Agriculture and Home Economics Experiment Station, Ames, Iowa, which is supported by USDA-National Institute of Food and Agriculture and State of Iowa funds.

\section{References}

Ajzen,I.1991.The theory of planned behavior. Organizational Behavior and Human Decision Processes, Theories of Cognitive Self-Regulation 50(2):179-211. https://doi. org/10.1016/0749-5978(91)90020-T.

Al-Kaisi, M., H.M. Hanna, and M.D. Duffy. 2008. Resource Conservation Practices: Consideration in Selecting No-till. Ames, IA: Iowa State University Extension.

Arbuckle, J.G. 2016. Iowa Farm and Rural Life Poll: 2015 Summary Report. Ames, IA: Iowa State University Extension.

Arbuckle, J.G. 2017. Iowa Farm and Rural Life Poll: 2016 Summary Report. Ames, IA: Iowa State University Extension.

Arbuckle, J.G., and G. Roesch-McNally. 2015. Cover crop adoption in Iowa: The role of perceived practice characteristics. Journal of Soil and Water Conservation 70(6):418-29. https://doi.org/10.2489/jswc.70.6.418.

Armstrong, A., R.C. Stedman, J.A. Bishop, and P.J. Sullivan. 2012.What's a stream without water? Disproportionality in headwater regions impacting water quality. Environmental Management 50(5):849-860.

Atwell, R., L. Schulte, and L. Westphal. 2009. Linking resilience theory and diffusion of innovations theory to understand the potential for perennials in the U.S Corn Belt. Ecology and Society 14(1). https://doi. org/10.5751/ES-02787-140130.

Baumgart-Getz, A., L.S. Prokopy, and K. Floress. 2012. Why farmers adopt best management practices in the United States: A meta-analysis of the adoption literature. Journal of Environmental Management 96(1):17-25. https:// doi.org/10.1016/j.jenvman.2011.10.006.

Bennett, H.H. 1939. Soil Conservation 1st edition. New York, NY: McGraw-Hill Book Company.
Bennett, H.H. 1943. Adjustment of Agriculture to its Environment. Annals of the Association of American Geographers 33(4):163-98. https://doi. org/10.2307/2561201.

Box, G.E., and P.W. Tidwell. 1962. Transformation of the independent variables. Technometrics 4(4):531-50. https://doi.org/10.2307/1266288.

Carlisle, L. 2016. Factors influencing farmer adoption of soil health practices in the United States: A narrative review. Agroecology and Sustainable Food Systems 40(6):583613. https://doi.org/10.1080/21683565.2016.1156596.

Claassen, R. 2004. Have conservation compliance incentives reduced soil erosion? Amber Waves. Washington, DC: USDA Economic Research Service. https://www.ers. usda.gov/amber-waves/2004/june/have-conservationcompliance-incentives-reduced-soil-erosion/.

Claassen, R., and E. Duquette. 2012. Additionality in U.S. agricultural conservation programs: A preliminary analysis of new data. Paper presented at the Agricultural and Applied Economics Association 2012 Annual Meeting, Seattle, WA, August 12-14, 2012.

Coppess, J. 2017. Historical background on the Conservation Reserve Program. Farm Doc Daily (7)82. UrbanaChampaign, IL: Department of Agricultural and Consumer Economics, University of Illinois.

Damanpour, F. 1996. Organizational complexity and innovation:Developing and testing multiple contingency models. Management Science 42(5):693-716.

Ervin, C.A., and D.E. Ervin. 1982. Factors affecting the use of soil conservation practices: Hypotheses, evidence, and policy implications. Land Economics 58(3):277-92. https://doi.org/10.2307/3145937.

Field,A.P. 2009. Discovering Statistics Using SPSS: (And Sex, Drugs and Rock ' $n$ ' Roll), 3rd edition. Thousand Oaks, CA: SAGE Publications.

Fishbein, M., and I. Ajzen. 2011. Predicting and Changing Behavior: The Reasoned Action Approach. Oxfordshire, UK: Taylor \& Francis.

Hair,J.F., Jr., W.C. Black, B.J. Babin, and R.E.Anderson. 2010. Multivariate Data Analysis: A Global Perspective 7th edition. Upper Saddle River, NJ: Prentice Hall.

Hair, J.F., W.C. Black, B.J. Babin, and R.E. Anderson. 2013. Multivariate data analysis: Advanced diagnostics for multiple regression [Online supplement]. Hoboken, NJ: Pearson Prentice Hall Publishing. http://www.mvstats. com/Downloads/Supplements/Advanced_Regression_ Diagnostics.pdf.

Helms, J. 2005. Technical assistance: The engine of conservation. Prepared for the Partnership Meeting, Natural Resources Conservation Service, March 15, 2005. Washington, DC: USDA Natural Resources Conservation Service.

IBM Corp. (International Business Machines Corp.). 2019. IBM SPSS Statistics for Windows.V. 26.0. Armonk, NY: IBM Corp.

IDALS (Iowa Department of Agriculture and Land Stewardship), IDNR (Iowa Department of Natural 
Resources), and ISU (Iowa State University) College of Agriculture and Life Sciences. 2017. Iowa Nutrient Reduction Strategy. Ames, IA: Iowa State University. http://www.nutrientstrategy.iastate.edu/.

ISU (Iowa State University, Agronomy Department). 2020. Corn Nitrogen Rate Calculator. Ames, IA: Iowa State University. http://cnrc.agron.iastate.edu/.

ISU Extension and Outreach. 2020. Crop and land use: Statewide data. Ames, IA: Iowa State University. https://www.extension.iastate.edu/soils/ crop-and-land-use-statewide-data.

Kalcic, M., L. Prokopy, J. Frankenberger, and I. Chaubey. 2014. An in-depth examination of farmers' perceptions of targeting conservation practices. Environmental Management 54(4):795-813. https://doi.org/10.1007/ s00267-014-0342-7.

Knowler, D., and B. Bradshaw. 2007. Farmers' adoption of conservation agriculture: A review and synthesis of recent research. Food Policy 32(1):25-48. https://doi. org/10.1016/j.foodpol.2006.01.003.

Kuhn, K. 2018. Benefits of Conservation Planning to Farmers, Landowners, and Society. Webinar. Ames, IA: Iowa Learning Farms. https://vimeo.com/ user42671352/review/290760563/4af1a07b69.

Liu, T., R.J. Bruins, and M.T. Heberling. 2018. Factors influencing farmers' adoption of best management practices: A review and synthesis. Sustainability 10(2):432. https://doi.org/10.3390/su10020432.

Lobry de Bruyn, L., and S. Andrews. 2016. Are Australian and United States farmers using soil information for soil health management? Sustainability 8(4):304.

Lobry de Bruyn, L., A. Jenkins, and S. Samson-Liebig. 2017. Lessons learnt: Sharing soil knowledge to improve land management and sustainable soil use. Soil Science Society of America Journal 8(3):427-438. https://doi. org/10.2136/sssaj2016.12.0403.

Lubell, M., and A. Fulton. 2008. Local policy networks and agricultural watershed management. Journal of Public Administration Research and Theory 18(4):673-96. https://doi.org/10.1093/jopart/mum031.

Luloff,A.E., J.C. Finley, W. Myers, A. Metcalf, D. Matarrita, J.S. Gordon, C. Raboanarielina, and J. Gruver. 2011. What do stakeholders add to identification of conservation lands? Society \& Natural Resources 24(12):1345-53. https://doi.org/10.1080/08941920.2011.589098.

Malone, L.A. 1985. A historical essay on the conservation provisions of the 1985 Farm Bill: Sodbusting, swampbusting, and the conservation reserve. Kansas Law Review 34(3):577-98.

Menard, S. 2002. Applied Logistic Regression Analysis Vol. 106, 2nd edition. Thousand Oaks, CA: Sage Publications.

Moritz, B. 2020. Who are the private landowners in the Midwest? Outdoor News Bulletin 74(9). Washington, DC: Wildlife Management Institute. https:// wildlifemanagement.institute/outdoor-news-bulletin/ september-2020/who-are-private-landowners-midwest.
Myers, R.H. 1990. Classical and Modern Regression with Applications, 2nd edition. Boston, MA: PWS-KENT.

NACD (National Association of Conservation Districts). 2017. Did You Know? National Conservation Planning Partnership. Washington, DC: National Association of Conservation Districts. https://www.nacdnet.org/2017/08/29/ know-national-conservation-planning-partnership/.

Nowak, P., S. Bowen, and P.E. Cabot. 2006. Disproportionality as a framework for linking social and biophysical systems. Society \& Natural Resources 19(2):153-73. https://doi. org/10.1080/08941920500394816.

Osmond, D., D. Meals, D. Hoag, M. Arabi, A. Luloff, G. Jennings, M. McFarland, J. Spooner, A. Sharpley, and D. Line. 2012. Improving conservation practices programming to protect water quality in agricultural watersheds: Lessons learned from the National Institute of Food and Agriculture-Conservation Effects Assessment Project. Journal of Soil and Water Conservation 67(5):122A-127A. https://doi. org/10.2489/jswc.67.5.122A.

Prokopy, L.S., K. Floress, J.G. Arbuckle, S.P. Church, F.R. Eanes, Y. Gao, B.M. Gramig, P. Ranjan, and A.S. Singh. 2019. Adoption of agricultural conservation practices in the United States: Evidence from 35 years of quantitative literature. Journal of Soil and Water Conservation 74(5):520-34. https://doi.org/10.2489/jswc.74.5.520.

Prokopy, L.S., K. Floress, A. Baumgart-Getz, and D. KlotthorWeinkauf. 2008. Determinants of agricultural best management practice adoption: Evidence from the literature. Journal of Soil and Water Conservation 63(5):300-311. https://doi.org/10.2489/jswc.63.5.300.

Ranjan, P., S.P. Church, K. Floress, and L.S. Prokopy. 2019. Synthesizing conservation motivations and barriers: What have we learned from qualitative studies of farmers' behaviors in the United States? Society \& Natural Resources 32(11):1171-99. https://doi.org/10 $.1080 / 08941920.2019 .1648710$.

Rasker, R. 2019. Public Land Ownership in the United States. Bozeman, MT: Headwaters Economics. https://headwaterseconomics.org/public-lands/ protected-lands/public-land-ownership-in-the-us/.

Reimer, A.P., and L.S. Prokopy. 2014. Farmer participation in U.S. Farm Bill conservation programs. Environmental Management 53(2):318-32. https://doi.org/10.1007/ s00267-013-0184-8.

Reimer, A., A. Thompson, L.S. Prokopy, J.G. Arbuckle, K. Genskow, D. Jackson-Smith, G. Lynne, L. McCann, L.W. Morton, and P. Nowak. 2014. People, place, behavior, and context: A research agenda for expanding our understanding of what motivates farmers' conservation behaviors. Journal of Soil and Water Conservation 69(2):57A-61A. https://doi.org/10.2489/jswc.69.2.57A.

Reimer, A.P., D.K. Weinkauf, and L.S. Prokopy. 2012. The influence of perceptions of practice characteristics: An examination of agricultural best management practice adoption in two Indiana watersheds. Journal of Rural
Studies 28(1):118-28. https://doi.org/10.1016/j. jrurstud.2011.09.005.

Rogers, E.M. 2010. Diffusion of Innovations. New York, NY: Simon and Schuster.

Schnepf, M., and C. Cox. 2006. Environmental Benefits of Conservation on Cropland:The Status of Our Knowledge. Ankeny, IA: Soil and Water Conservation Society.

Scott, J.M., D.D. Gobel, and F.W. Davis (Eds). 2006. The Endangered Species Act at Thirty,Volume 2: Conserving Biodiversity in Human-dominated Landscapes. Washington, DC: Island Press.

Singh, A.S., F.R. Eanes, and L.S. Prokopy. 2018. Assessing conservation adoption decision criteria using the analytic hierarchy process: Case studies from three Midwestern watersheds. Society \& Natural Resources 31(4):503-7. https://doi.org/10.1080/08941920.2017 .1413694 .

Swanson, L.E., S.M. Camboni, and T.L. Napier. 1986. Barriers to adoption of soil conservation practices on farms. In Conserving Soil: Insights from Socionomic Research., ed. S.B. Lovejoy and T.L. Napier, 108-20. Ankeny, IA: Soil Conservation Society of America.

Tabachnick, B.G., and L.S. Fidell. 2014. Using Multivariate Statistics. Harlow, Essex: Pearson Education Limited.

USDA NASS (National Agricultural Statistics Service). 2014. 2012 Census of Agriculture. Washington, DC: USDA. https://www.nass.usda.gov/Publications/ AgCensus/2012/.

USDA NASS. 2019.2017 Census of Agriculture. Washington, DC: USDA. https://www.nass.usda.gov/Publications/ AgCensus/2017/index.php.

USDA NRCS (Natural Resources Conservation Service). 2006a. Electronic Directives System, General Manual, M.440.A.525.01 Conservation Technical Assistance Program. Washington, DC: USDA NRCS. https://directives.sc.egov.usda.gov/ViewRollUp. aspx?hid $=17120 \& \mathrm{sf}=1$.

USDA NRCS. 2006b. Electronic Directives System, General Manual, M.440.C.525.20 Delivering Conservation Technical Assistance. Washington, DC: USDA NRCS. https://directives.sc. egov.usda.gov/RollupViewer. aspx?hid=17131.

USDA NRCS. 2007. Electronic Directives System, General Manual, M.450.401.C.20 Resource Management System quality criteria and guidance documents. Washington, DC: USDA NRCS. https://directives. sc.egov.usda.gov/viewerFS.aspx?hid=19431.

USDA NRCS. 2010. What is a Conservation Plan? Washington, DC: USDA NRCS. https://www. nrcs.usda.gov/Internet/FSE_DOCUMENTS/ nrcs141p2_018353.pdf.

USDA NRCS. 2012. Unlocking the Secrets of the Soil. Washington, DC: USDA NRCS. https://www. nrcs.usda.gov/wps/PA_NRCSConsumption/ download/?cid $=$ nrcseprd855206\&ext $=$ pdf.

USDA NRCS. 2013a. National and State Resource Concerns and Planning Criteria. Washington, 
DC: USDA NRCS. https://www.nrcs. usda.gov/wps/PA_NRCSConsumption/ download?cid $=$ nrcseprd1350226\&ext $=$ pdf.

USDA NRCS. 2013b. National Planning Procedures Handbook (NPPH), Amendment 5. Washington, DC USDA NRCS. https://directives.sc.egov.usda.gov/ OpenNonWebContent.aspx? content $=33234$. wba.

USDA NRCS. 2016a. Electronic Directives System, General Manual, 180-409-GM Conservation Planning Policy. Washington, DC: USDA NRCS. https:// directives.sc.egov.usda.gov/OpenNonWebContent. aspx? content $=39113$.wba.

USDA NRCS. 2016b. How NRCS Financial Assistance Programs Work. Amherst, MA: USDA NRCS. https:// www.nrcs.usda.gov/wps/PA_NRCSConsumption/ download? cid $=$ nrcseprd888659\&ext $=$ pdf.

USDA NRCS. 2020a. Natural Resources Conservation Service Iowa-About us. Des Moines, IA: USDA NRCS. https://www.nrcs.usda.gov/wps/portal/nrcs/ ia/about.

USDA NRCS. 2020b. Conservation Planning: Productive Lands, Healthy Environment. Washington, DC USDA NRCS. https://www.nrcs.usda.gov/wps/ portal/nrcs/detail/national/programs/technical/ cta/?cid=stelprdb1049425.

USDA NRCS. 2020c. Mission and Vision. Washington, DC: USDA NRCS. https://www.nrcs.usda.gov/wps/portal/ $\mathrm{nrcs} /$ detailfull/national/about/?cid=nrcseprd1547221.

USDA NRCS. 2020d. Honoring 85 Years of NRCS - A Brief History. Washington, DC: USDA NRCS. https:// www.nrcs.usda.gov/wps/portal/nrcs/detail/national/ about/history/?cid=nrcs143_021392.

USDA NRCS. 2020e. Farm Bill. Washington, DC: USDA NRCS. https://www.nrcs.usda.gov/wps/portal/nrcs/ main/national/programs/farmbill/.

USDA NRCS. 2020f. Purpose of the CTA Program. Washington, DC: USDA NRCS. https://www.nrcs. usda.gov/wps/portal/nrcs/detail/national/programs/ technical/cta/?cid=nrcs143_008365.

USDA NRCS. 2020g. NRCS Strategic Plan Update FY2016-2018. Washington, DC: USDA NRCS. https:// www.nrcs.usda.gov/wps/PA_NRCSConsumption/ download $/$ ?cid $=$ nrcseprd1332649\&ext $=$ pdf.

USDA NRCS. 2020h. Technical Assistance. Washington, DC: USDA NRCS. https://www.nrcs.usda.gov/wps/portal/ nrcs/main/national/programs/technical/.

USDA NRCS. 2020i. Buffer Strips: Common Sense Conservation. Washington, DC: USDA NRCS. https:// www.nrcs.usda.gov/wps/portal/nrcs/detail/national/ home/?cid=nrcs143_023568.

USDA OBPA (Office of Budget and Program Analysis). 2020. USDA FY 2021 Budget Summary. Washington, DC: USDA.

Wheaton, R., and E. Monke. 2001. Terracing as a 'Best Management Practice' for Controlling Erosion and Protecting Water Quality. West Lafayette, IN: Purdue University Cooperative Extension Service.
White, C. 2018. Will your nitrogen stabilizer be effective? University Park, PA: Penn State Extension. https://extension.psu.edu/ will-your-nitrogen-stabilizer-be-effective.

Wilkinson, R. 2011. The many meanings of adoption. In Changing Land Management: Adoption of New Practices by Rural Landholders, ed. D.J. Pannell and F. Vanclay, 39-49. Collingwood,Australia: Csiro Publishing. Woods, B.R., A.E. Luloff, D. Osmond, and D. Hoag. 2014 Toward a synthesis: Lessons from thirteen cropland watershed-scale studies. Society \& Natural Resources 27(4):341-57. https://doi.org/10.1080/08941920.201 3.861551 . 